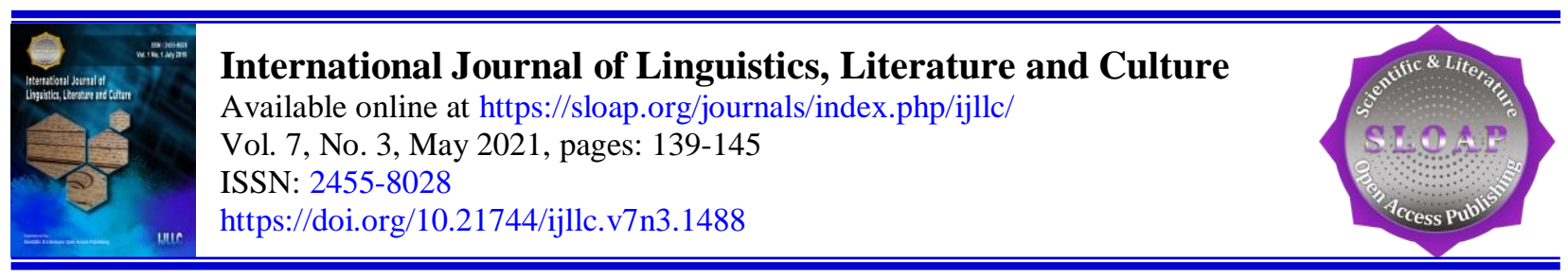

\title{
About the Talismans of Iskandar (Alexander) by Alisher Navoi
}

Ilyos Ismoilov ${ }^{\text {a }}$

Article history:

Submitted: 9 February 2021

Revised: 27 March 2021

Accepted: 18 April 2021

\section{Keywords:}

alexandria minaret;

artistic image;

literature;

looking glass;

mysterious reflection;

technical discovery;

Abstract

There were many scientific discoveries in the history of mankind. They were widely spread among the people and influenced various branches of science. Most scientific discoveries, although of Russian, technical nature, had a strong influence on the humanities and were widely used. For example, one of the main objects of the image of literature was scientific discoveries, historical miracles. The creators described in their works their views on the role of Science in the life of society, its importance for mankind, through various scientific debates, the description of discoveries. One of such scientific discoveries was the mirror of Alexander the Great (Iskandar), widely described in Eastern literature and became an important traditional image. In the article, the image of Alexander the Great, which played an important role in Eastern literature, the history of its creation, its peculiarities and genesis were studied in comparative aspect. The views on the Alexandria minaret are also analyzed and it is proved that the Alexandria minaret, widely described in Eastern literature, is the lighthouse of Alexandria, one of the Seven Wonders of the world. It is based on the works of geographers and historians Mas'udi (IX century), Nasir Khisrav (XI century), Mirkhond bin Khovandshah (XV century), as well as on the works of poets such as Nizami Ganjavi (XII century), Khusrav Dehlavi (XIII century) and Alisher Navoi (XV century), friends of Alexander. The main emphasis is on the analysis of Alisher Navoi's works.

International journal of linguistics, literature and culture (C) 2021. This is an open access article under the CC BY-NC-ND license (https://creativecommons.org/licenses/by-nc-nd/4.0/).

Corresponding author:

Ismoilov, I.

103 O'qituvchi st., Тошкент, Uzbekistan

Email address: ismoilov_iles@mail.ru

a Tashkent State University of Uzbek language and literature, Tashkent, Uzbekistan 


\section{Introduction}

In the distant past, many scientific discoveries were made by mankind. Science and various technical discoveries developed directly due to such important milestones as the necessity in social life, the political situation and the ease of the hardship of people, and influenced various branches of science. In particular, many scientific discoveries, technical developments, as well as scientific predictions were written in the literature. It should be noted that literature has not only recorded existing scientific discoveries, but also widely described scientific hypotheses, scientific prophecies that concern the whole of mankind. Because literature was directly related to such qualities as man's creative abilities, inspiration, fantasy and intuition. It's no secret that in the light of today's technical progress, the above abilities inherent in humans stand out.

In the absence of a scan in literature, the image of technical discoveries occupies a wide place in a particular category of works. Such events, especially great historical figures, are interpreted in connection with their activities. One of such great personalities in Eastern literature is Alexander The Great (Iskandar), many scientific discoveries are directly connected with his activities.

\section{Literature Review}

Until now, one of the scientific discoveries widely described in Eastern literature Alexander the Great has not been specially studied in the context of literary criticism. The issue of the impact of information from the first historical and geographic sources on the work of art literature, in particular, Alisher Navoi, was not investigated separately. But in the works devoted to the analysis of various "Alexandrian books", some opinions were expressed.

Russian Orientalist Y.E.Bertels studied in his research (Bertels, 1965; Xiong et al., 2021) mainly the genesis of the image of Alexander, the Persian sources depicting the image of Alexander, as well as their influence on the creativity of Navoi. Although the scientist analyzed the "Alexandrian books" written by Firdavsi, Nizami, Khusrav, Ahmadi and Navoi, he did not pay serious attention to the image of Alexander the great. Y.A.Kostyukhin drew attention to the connection of the image of Alexander with the traditions of more folklore and written literature (Kostyukhin, 1972). In it, such issues as the mirror of Alexander and the tower of Alexandria were not addressed, although the partial analysis of the epic of Alisher Navoi "Saddi Iskandari" was made.

I.Pala his study focuses the main attention on the identification of the personality of Alexander and Dhu'lQarnayn, in part on mirror motivation, which was also emphasized (Pala, 1990). M.Turkdugan studied the epic of "Iskandarnoma" created by Ahmadi in the Turkic language (Türkdoğan, 2009), I.Avji is a Turkic network of Alexandrian books, their connection with folklore, in particular, studied the epic of Ahmed Rizwani "Iskandarnoma" (Avc1, 2015, Avc1, 2013). A.Qayumov explained his observations on the ideological and philosophical content, main images of Navoi's "Saddi Iskandari" epic (Kayumov, 1975; Aigerim et al., 2013), F.Suleymanova addressed the Alexander theme within the framework of ancient and medieval cultural relations (Sulaymonova, 1997). In them, the mirror of Alexander was not studied.

In the research of Doufikar-Aerts, mainly Arab stories about Alexander, when their evolution is studied (DufikarAerts, 2010), a special study about Alexander Mirror is also not found in the monograph "The Alexander Romance in Persia and the East", published by the editor of Richard Stoneman (Stoneman, 2012). In the study of Sayidhasan Safavi titled "Alexander and Iranian literature", works on Alexander created in Persian were analyzed and information about Alexander window was given on the way (Safavi, 1364; Uralov, 2020).

\section{Materials and Methods}

In today's philology, the study of increasingly genetic and typological literary links is becoming significantly importance of paramount importance. Comparative aspect is also significant in that it reflects the peculiarities of the literary process and helps to understand the logic of the action of the world literary process. Comparative-historical and descriptive methods were used in the article in accordance with the given scientific problem and the above requirements. In the works of Alisher Navoi in the solution of the issues related to Alexander the great looking glass and Alexandria minaret, mainly the descriptive method was used. The comparative-historical method was used to compare the views of Nizami, Khusrav and Navoi on Alexander's minaret and Alexander's window in comparison with the historical data and artistic facts. 


\section{Results and Discussions}

\section{Main Part}

One of the important images of the stories about Alexander, created in the East, was a mirror (oina), which romanced the creators as a motivation, demonstrating the wisdom of Alexander and the owner of virtues. In almost all of the stories about Alexander, including in the work of Alisher Navoi, important information about the mysterious mirror is the technical discovery attributed to Alexander. About the history of the creation of the window, some of its features are recorded in the works of Navoi "Saddi Iskandari", "History of anbiyo and hukamo", "Leyli and Majnun".

\section{The first mirror to which Alexander is attributed}

Alisher Navoi writes that "Saddi Iskandari" is an image of poem Iskandar's journey to China, and among the gifts presented to Khaqon Iskandar is "oinayi chin" (mirror of chin). A strange feature of the mirror was that always two faces stood as bright as the lunar Sun. The wise men spun two features on the two faces of the mirror, and if the mahal, who was listening to the people's petition, rejected the second party's claim, it would be sufficient if the witness looked in the speaker's mirror to determine the truth he did not need. If true, then the face in the mirror was visible, if false, it was invisible. The second face of the mirror was made of such a talisman that if the King was on the feast, the sometimes would look at the mirror in the assembly. In the norm, the face of those who drank may reflected in the mirror in its own way, the face of the badmasts would appear in Long, Short, Leaf forms. As a result, many drinkers used to take a measure to save themselves from discomfort.

Alexander from this unique gift will be incredibly surprised and will really find wintering, creating a mirror of steel along with philosophers. This is the first Alexander the great looking glass, which was made of porcelain and was considered to belong to Alexander. It was thought that he had an aval form and was considered a talisman. It is understood that the mysterious feature of this mirror is in the ability to show human destiny. Navoi described the artistic interpretation of this window on the example of the fate of the protagonist Farhad, the epic "Farhad and Shirin".

The second mirror, which is attributed to Alexander

Navoi gave information about the second window of Alexander the great interesting to us in the works "Leyli and Majnun" and "The history of prophets and wise men". This is how Navoi describes "Leyli and Majnun" as a friend:

E ishq, g'arib kimiyosen,

Bal oinayi jahonnamosen (Navoi: 1992, p. 271).

(It means : oh love, you are a wonderful chemical, not only a chemical but also the shown mirror the world).

Navoi couplet talks about two important features of love such as chemistry and world view. The second feature of the work, which dictates the theme of Alexander the great, is that Navoi uses the image of Alexander the great for poetic reasoning of this virtue.

Navoi love is based on the theory of manifestation (glancing) (the view in Sufism), when there are words about the lightening of the universe, like a mirror indicating it. According to this theory, in all things in the universe there are sparks of divine truth, particles of divine light, which can only be perceived by the eyes of the soul. That is, from what is created, the creator is understood, the ornament from the pattern, usually such a virtue is possessed by Wise Men, Sufis. When they look at the side because of their pure love, they will see the yor (as the Majnun sees Leyli on all sides), the essence of the events and the husband will be aware from the Blue secret. Therefore, Navoi love is called a mirror showing the world, informing the world.

In this way, Navoi puts forward the poetic idea that it is not right to call The Mirror made in Rim by Alexander jahonnamo (experienced person) in order to further emphasize the worldview of the feeling of love. For comparison, Alexander also gives a brief description of the window: when Alexander polished steel and made a window, in Rim Farang (Pharangistan, Europe) will build a tower facing the side. They give such a gloss to the mirror, as a result of

Ismoilov, I. (2021). About the Talismans of Iskandar (Alexander) by Alisher Navoi. International Journal of Linguistics, Literature and Culture, 7(3), 139-145. https://doi.org/10.21744/ijllc.v7n3.1488 
which it will be bright enough to indicate a farang. When the mirror is so bright, Alexander calls it a reflection of the world (Navoi, 1992). This is the second mirror to which Alexander is attributed in Eastern sources.

Alisher Navoi "Saddi Iskandari" did not give information about this second Alexander miror. But Navoi in the book "The History of the prophets and wise men" writes about Balinos (Greek wisdom), one of the Greek philosophers: "the wise Balinos is the disciple of Aristotle. The Balinos had made the talisman of the Alexandria minaret visible from what the Europeans had done" (Navoi, 2000). Navoi should rely on the work "History guzida" (history of the past) in this regard. Because he actively appealed to this source when writing his historical works, the data on the Balinos are similar to the facts about the Balinos in his work in the "History guzida" (Mustafi, 1339). So the original name of the construction, which Alexander built, is "Alexandria minaret", and it was spun. But about the talisman of the Navoi tower does not say anything. It seems that something is rare even when the mirror in the border Tower is considered to be incredibly bright and clear, reflecting its work at a very distant distance.

\section{Debate and Results}

There are records of Nizami Ganjavi's "Iskandarnama" poem about both mirror attributed to Alexander. According to the charter, Alexander the first window in the world was made and the man who first looked in the mirror was also Alexander (Nizomii, 2012). Brief details of the mirror of the second Alexander, recorded by Navoi, are given in the second part of the charter "Iskandarnama". Nizami notes that the famous tower was built in Alexandria, on top of which a huge window was installed, indicating all the visible phenomena on the surface of the River at a distance of one month, when the tower guards saw an event in the window, they would deliver it to the state guards, and they would take action against the enemy inadvertently.

Khusrav Dehlavi took a special way about the window. In order to emphasize the originality of his work, his new thoughts on the mirror image, he not only described the history of the mirror in the epic, but also raised it to the level of the name of the work and called the name of his work "Oinayi Iskandari" (Mirror of Alexander). Khusrav Dehlaviy believes that the first window in the world, which he refers to Nizami Alexander, actually belongs to the chin Khan. Khusraw cites a legend that reflects the bet of the Gypsies and Roman carvings as evidence for this. Amir Khusrav at the end of the story writes that Alexander was surprised to see the Mirror in which the porcelain ornaments were embroidered:

Chu kam dide bed oina pesh az on,

Badidan on va shud dast hayratgazon (Dehlavi: 1977, p. 141).

(Meaning: he had never seen a mirror before, so he pricked his finger in amazement as soon as he saw it)

According to Khusrav, the first window to which Alexander was attributed, in fact, belongs to the peoples of the East (Khakon), the Romans were unaware of the mirror at these times.

In the poem called the "Mirror of Iskandar", he is described as having built the Alexandria minaret very high on The Rim River at the request of the ambassador, who later complained about the European robber and the thieves. The tower is set in step towards the fangs and a huge window is installed on top of it, reflecting the poles at a distance of 60 Fars (length of about $40-50 \mathrm{~km}$ ). Through it, political goals were pursued, such as monitoring the sea and avoiding the attack of Pirates. Khusrav Dehlavi believes that when he says "Alexander the mirror", it is necessary to refer to the mirror installed in this minaret, and Alexander firmly emphasizes that he did not create another window.

Although Navoi's views on mirror of Alexandria are close to Amir Khusrav, they have printsipial differences. Navoi also admits that the mirror with a talisman was in chinlik before the Greeks. However, Navoi Amir Khusrav believes that a mysterious mirror similar to the mirror, which he refers to chin, was also made by Alexander. Therefore, when Navoi says the mirror of Alexander in his work, he refers to two mirrors:

One of them. The first mirror of Alexander made by a hundred masters in China.

Two. The looking glass of Iskandar put in the Alexandria minaret.

And Amir Khusrav believes that there is only one Alexander window. But both Nizami and Navoi Alexander have created two windows. Khusrav entered into the information of the Nizami about the Alexandria minaret by robbers, some clarifications about the location and distance of the minaret. It should be noted that the Navoi about the 
Alexandria minaret is more suitable for the image of Khusrav Dehlavi. The Nizami minaret is located in Alexandria, Khusrav is on The Rim River, and Navoi is on The Rum. Nizami does not indicate where the tower and the window are facing and Khusrav and Navoi clearly stated that it is Farang side. If the charter window says that one month, 60 persian acts are reflected in the distance, Navoi Farang notes that his actions are visible. Nizami and Khusrav made it clear that the aim of this work is the country's defense, Navoi does not openly state the purpose of the window, but the construction of the window facing Farngistan, which means that a political goal is being pursued, as can be seen from the Farang movement.

\section{Alexandria minaret - Alexander Lighthouse}

In some historical works created in the east, information was preserved about the Alexandria minaret and the huge window built into it. According to Mirkhond (XV century), at one edge of the city of Alexandria, a tower with a height of 600 gas (an ancient unit of measurement) was built, on top of which was made a mirror talisman. He used to show those who had taken out of the surrounding areas a deliberate army of the city. If the people of the city had voqif from such an action, it would have taken a measure to repel the enemy (Mirkhand, 1338).

Nasir Khisrav (1004-1088) writes about this structure: Alexandria is also located on the shores of The Rim sea and the Nile River. And from there they bring a lot of fruits to Egypt on ships. Alexandria was a beacon, and when I saw bus-the whole. A burning window is installed at the top of the lighthouse. If the Rum ships from Istanbul reach the circle of its influence, the fire falls from the window to the ship and burns. The Romans tried very hard to get rid of it, invented various tricks and finally sent a man and broke this window (Khisrav, 2003).

The Arab historian and geographer Mas'udi (IX century) wrote valuable information about the Alexandria minaret (Mas'udi, 1374). According to him, the buildings of the city of Alexandria were built by Alexander Makduni, son of Faylaqus, some thought that the minaret there was built by Malika Dalv and made him a observation punk, through which he observed the enemies attacking Egypt. Some believe that the minaret was built by Pharaoh X. Another group of Roman cities also attributed the construction of Alexandria to Alexander because he built towers and ehroms of Egypt, Alexander had gained fame with his municipality to most of the countries of the world, so this city was also famous for its name. It remains to be said that from the Greek River enemies Alexander did not make a move and Alexander was not afraid of a royal move.

Mas'udi noted that the foundation of the Alexandria minaret was built in the form of a crab, in a river from a bottle, and on top was installed a body of various shapes, figurines made of copper and other metals. One of these bodies would bend his hand with his thumb, pointing it in accordance with the movement of the sun, and the dwelling would lower his hand when the sun went down. If one of the other attacks the enemy at night, daryoga the sign, and when the enemy came close, a two to three-mile audible alarm would sound, as a result of which the population would find a message of the proximity of the enemy. Another body would produce an unusually pleasant sound from its usual sound every hour of the day at night.

During the reign of Walid bin Abdulmad bin Marwani, the Roman king sends one of his peculiar servants to Alexandria, who, having achieved high positions, becomes a Muslim and is close to King Walid. He believes that under the minaret of Alexandria the king there is also an inexhaustible treasure and persuades the king to break the minaret, seeing the wealth of Walid because of the hoards in Damascus and other Muslim cities. When the minaret was destroyed, they knew that the case was a scam, but at that time the Greek worker had fled to his land (Mas'udi, 1374).

The rulers of Alexandria installed a huge window on the top of the tower so that they could see the enemy coming from the river towards them. The reason for this was the danger that the Roman princesses after Alexander came with the aim of fighting with the Kings of Alexandria and Egypt. Those who did not know the entrance doors to the tower would go without a trace if they entered the tower, because inside the tower there were a lot of rooms, doors and corridors, they say, the Maghreb invaded Alexandria during the era of the Caliphate, of which a group of cavalry entered the tower and disappeared without a trace. There were such roads inside the tower that they would lead from the glass to the bottom of the tower, which was built in the form of a crab, and from there there were dachas (Mas'udi, 1374).

As we get acquainted with these data from Eastern sources, the Alexander Lighthouse, recognized as one of the Seven Wonders of the subconscious world, comes to mind.

The second name is the Faros Lighthouse - The Lighthouse of Alexandria. It is built on a rock and is located on the east coast of the island of Faros, close to the shores of Egypt. The lighthouse was founded by Alexander's commander Ptolemy the Soter in BC. It began in 285-th year and graduated in 280 - th year. The total height of this

Ismoilov, I. (2021). About the Talismans of Iskandar (Alexander) by Alisher Navoi. International Journal of Linguistics, Literature and Culture, 7(3), 139-145. https://doi.org/10.21744/ijllc.v7n3.1488 
three-storey minaret is about 120 meters. The lower floor is rectangular in shape, taking into account the fact that the light falls from the North, East, South and West when determining its four sides. The second floor is in the form of an eight-pointed tower, taking into account the blowing of the wind from the eight sides. The third floor is in the form of a dome, in which a fire is lit. On the third floor there is a huge monument of the sea god Poseidon creatted 7 meters from the bronze. The dome is raised by polished granite columns. Here, in order for the fire to be lit and the sea passengers to be seen from the Far side, special processing mirrors were installed on the iron in order to further convey the flame generated from the flame.

The Lighthouse also performed the function of a tracking Punk at the same time as providing a way for Sea passengers. In this steel-fired windows in the minaret were combed by enemy ships that appeared at sea level. The second floor with eight sides of the building was decorated with many bronze figurines, which were moved with a simple sound indicating the speed and movement of the wind, the passengers saw the Faros lighthouse and talked about the miraculous statuettes. For example, one of the figurines was a mansion with a ram, always showing the direction in accordance with the sun, lowered his hand, while another statuette hit the bong every hour of the night, while the other drew his hand to the sea, warning of danger when the enemy fleet approached (Neyxardt \& Shishova, 1966).

\section{Conclusion}

So the details about the Tower, which the Nizam, Khusrav and Navoi depicted in their friends, and the mirror of Alexander installed on it, belong to the world-famous Alexandrian Lighthouse. Reflections on the Alexandrian Lighthouse have not changed in any way for two thousand years, nevertheless, it has not lost its main character in the Eastern sources. For example, in the work of eastern poets, the image of the lighthouse on the way to the harbor became blurred and the country served for defence was more preserved.

If the area where the Nizami lighthouse is located is correctly called Alexandria (Alexandrian), Khusrav and Navoi indicate this place as Rum and note that the name of the building is "Alexandria minaret". Perhaps the author of the source used by Navoi considered the land on which the lighthouse was located to be Rum, or Alexander called Rum (like the Roman Empire) with a common name, since it also subordinated the lands. By the way, the lighthouse is not entirely located on the territory of Egypt, although the island of Faros is closer to the shores of Egypt than Rome. Navoi clearly notes that the minaret is built facing Europe, in fact, the north-eastern part of Egypt facing Europe is covered by the sea, and the island of Faros is located here. Another of the important information given by Navoi is that the mirror in the minaret was made by processing. Historical sources also confirm that the mirrors in the lighthouse were made of metal. In addition to naming the Navoi lighthouse as the Alexandria minaret (Alexandrian lighthouse) in its own name, it is also noted that the minaret is a talisman and the talisman is made of Balinos. It seems that Navoi is not mistaken about the fact that the minaret is tilsymly. According to historical sources, Sea passengers saw bronze sculptures, which were simple enough to hang on the second floor of the Alexandrian lighthouse and imagined the minaret as a miracle, naturally among these passengers were also Orientals.

The differences in the image of the Nizami, Khusrav and Navoi on the tower and the window were caused by their bias to the issue. If the emphasis is on the intended purpose of the minaret more because it focuses on the political aspect of the charter, Khusrav will pay serious attention to clarifying the history of the creation of the window and the issue of "Oinayi Iskandari" in order to interpret the name of his friend and highlight his original views on the mirror of Alexander. As Navoi explains the nature of love, he paid more attention to the brilliance of the mirror in the Alexandria minaret, the world.

\section{Conflict of interest statement}

The author declared that (s)he has no competing interests.

\section{Statement of authorship}

The author has a responsibility for the conception and design of the study. The author has approved the final article.

\section{Acknowledgments}

I am grateful to two anonymous reviewers for their valuable comments on the earlier version of this paper. 


\section{References}

Aigerim, K., Kulmeskhan, A., Gaziza, K., \& Asem, A. (2013). Synthesis of achievements of world mankind in humanity pedagogy. Procedia-Social and Behavioral Sciences, 89, 886-889. https://doi.org/10.1016/j.sbspro.2013.08.950

Amir Khusravi Dehlavi. (1977). Oinayi Iskandariy. The text is critical. - Moscow: Nauka.

Arrian. (1962). Alexander's walk. - Moscow-Leningrad: Nauka.

Avcı İ. (2013). Türk Edebiyatında İskendernâmeler ve Ahmed-i Rıdvân'ın İskendernâme'si (doktora tezi), - Balıkesir.

Avcı İ. (2015). Alexander the Great in Azerbaijani Turkish Literature // Remarks on Turkish Studies. -Warsaw.

Avcı İ. Divan Şiirinde İskender'i Zülkarneyn // The Journal of International Social Research. 29 Volume: 7 Issue: 29.

Bertels Y.E. (1965). Selected Works. Volume 4. Navoi and Jami. - Moscow: Nauka.

Dufikar-Aerts, F. (2010). Alexander Magnus Arabicus. Leuven.

Kayumov A. (1975). Saddi Iskandari. - Tashkent: Literature and Art Publishing named after Gafur Gulom.

Khisrav Nosir. (2003). Safarnoma. - Tashkent: Sharq. 112 p.

Kostyukhin. E.A. (1972). Alexander the Great in literary and folklore tradition. - Moscow: Science.

Mas'udi Ali binni Al-Husayn. (1374). Muruj al-zahab. Volume 1. - Tehran: Scientific and Cultural Company.

Mirkhand Muhammad bin Khovandshah. (1338). Ravzat us-safo. Volume 1. - Tehran: Piruz.

Mustafi Hamidullah. (1339). In the guzi of history. - Tehran: Amir Kabir.

Navoi Alisher. (1992). Layla and Majnun. 20 volumes. 9 tom. - Tashkent: Fan.

Navoi Alisher. (2000). Historical prophets and rulers. 20 volumes. 16 vol. - Tashkent: Fan.

Navoi Alisher. (2000). Saddi Iskandariy. 20 volumes. 11 tom. - Tashkent: Fan.

Neyxardt A.A., Shishova I.A. (1966). Sem chudes drevnego mira. - Moscow: Nauka.

Nizomii Ganjaviy. (2012). Hamsa: Iskandarnoma. - Dushanbe: Adib.

Pala I. (1990). “Iskender mi Zulkarneyn mi?”. Journal of Turkish Studies, Vol. 14. p. 387 - 403.

Safavi Sayidhasan. (1364). Alexander and Iron Literature. - Tehran: Amir Kabir.

Sulaymonova F. (1997). East and West. - Tashkent: Uzbekistan. pp. 98-161.

The Alexander Romance in Persia and the East. (2012). Edited by Richard Stoneman. - Groningen: Barkhuis Publishing \& Groningen University Library. p. 416.

Türkdoğan, M. G. (2009). “Ahmedi’nin “Iskendernâme”sinde kadin hükümdar modeli ve kraliçe Kaydafa”, Turkish Studies - International Periodical For the Languages, Literature and History of Turkish or Turkic. Volume 4/7, p. $760-773$.

Uralov, O. S. (2020). Internationalization of higher education in Uzbekistan. Social Sciences \& Humanities Open, 2(1), 100015. https://doi.org/10.1016/j.ssaho.2020.100015

Xiong, M., Zhang, Q., Hu, W., Zhao, C., Lv, W., Yi, Y., .. \& Wu, Y. (2021). The novel mechanisms and applications of exosomes in dermatology and cutaneous medical aesthetics. Pharmacological Research, 105490. https://doi.org/10.1016/j.phrs.2021.105490

Ismoilov, I. (2021). About the Talismans of Iskandar (Alexander) by Alisher Navoi. International Journal of Linguistics, Literature and Culture, 7(3), 139-145. https://doi.org/10.21744/ijllc.v7n3.1488 